\section{Layered double hydroxides structure and composition influence on sorption characteristics relative to chromium anions}

Eleonora BUTENKO - Azov Sea State Technical University - butenkoeo@rambler.ru ALEXEY KAPUSTIN - Azov Sea State Technical University - kapustin_a_e@pstu.edu Received: 02.11.2009. • Érkezett: 2009.11.02. http://dx.doi.org/10.14382/epitoanyag-jsbcm.2010.9

This work deals with the investigation of heavy metals anions sorption from water phase by clay minerals of different composition. The basicity of sorbents, the kinetics of the sorption process, the anion-exchange capacities of clays with different cation composition have been studied. The correlation of exchange properties of clays on their composition has been founded. Keywords: layered double hydroxides, sorption, basicity, kinetic

\section{Introduction}

The adsorption cleaning of sewages is the most effective for deleting of heavy metals from sewages. The widely used sorbents are the active carbons of different modifications, but the use of active carbons is limited by their high cost. And yet, the sorption of heavy metals by active carbons is a physical process; there is no bond between the ions and the matrix, so the equilibrium process is possible. It does the processes of storage very risky because of possible of reverse desorption process. Also, the modified carbon sorbents investigated before possessed such draw backs, as the protracted establishment of sorption equilibrium and small degree of adsorption. So the investigation of new alternative sorbents for heavy metal ions is very important.

The aim of our work was to investigate new sorbents and to create a new technology for ions adsorption from liquid phase. The objects of our researches were oxides layered double hydroxides (LDHs), the most widespread clay minerals [1] with properties of inorganic anion-exchangers [2].

Most LDHs are the substances, showing cation-exchange properties. They are widely known and studied [1]. LDHs with properties of solid bases and anion exchangers known very restrictedly [3].

In general LDHs are natural or synthetic minerals, consisting of the positively charged layers in which there are molecules of water and anions liable to exchange. LDHs have the different basic sites [4]. The weak Bronsted sites are the hydroxide group of the hydrated surfaces and strong Lewis sites in the pair of $\mathrm{O}^{2-}-\mathrm{M}^{\mathrm{I}+}$, which can convertible pass from one form in other.

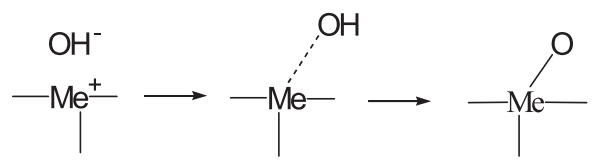

The basicity of LDHs depends on correlation of cations, calcing temperature, composition, structure [5]. In addition, adsorption ability of LDHs is determined by their spatial structure, size of interlayed space and correlation of sizes
Eleonora BUTENKO

is working at Department of Chemical Technology and Engineering, Azov Sea State Technical University. She had Bachelor of Science in Chemistry (2006) and Master of Science at Analytical Chemistry (2007) at Donetsk National University, Chemistry Faculty. She had a technician practice at Steel work "Azovstal" (2006). She was technician and later graduate student at Department of Chemical Technology and Engineering, Azov Sea State Technica University (2007). Her main field of interest is research of processes of physical sorption and anion-exchange of organic compounds on LDHs help solve environmental problems. She's 22 scientific publications.

Dr. Alexey KAPUSTIN (1958) is Doctor of Science (Chemistry). He's learned at Moscow Mendeleev Chemica Technological Institute (1975-1981). His PhD thesis was "Alcohol Ethoxylation Reactions" in 1983. His Doctor thesis was "Creation of Basic Heterogeneous Catalysts" in 1996. He's been working at Azov Sea State Technical University from 1984. Now he's Head of Department of Chemical Technology and Engineering of Azov Sea State Technical University, Mariupol, Ukraine.

and geometry of cations and internal space of LDH. Heat treatment of LDHs after adsorption of heavy metal ions results in formation of spinel-like structures that remain constant under the action of ground-waters and other environmental conditions:

$$
\mathrm{Mg}_{\mathrm{x}} \mathrm{Al}_{\mathrm{y}}(\mathrm{OH})_{\mathrm{z}} \rightarrow \mathrm{xMgO} \cdot \mathrm{yAl}_{2} \mathrm{O}_{3}
$$

\section{Experimental}

The LDHs were obtained in accordance with a method, described in [6]. The concentrations of $\mathrm{Mg}^{2+}$ and $\mathrm{Al}^{3+}$ should be such that approximately $10 \mathrm{~g}$ of dry mineral results per liter reagents. An aqueous solution of magnesium and aluminum nitrates is added rapidly and with good stirring to a solution of sodium hydroxide-carbonate at room temperature. The final $\mathrm{pH}$ should be between $8-11$. The amount of caustic used should be twice the magnesium and three times the aluminum moles used. The carbonate should approximate three or more times stoichiometric requirements. Following this the heavy gel is allowed to crystallize by heating at $80^{\circ} \mathrm{C}$ for varying periods of time, usually $18 \mathrm{~h}$. This results in a slurry which can normally be filtered quite readily, the higher the crystallization temperature and the longer the time, the more facile is the filtration and washing step.

In order to investigate the basic properties of LDHs the titration with Hammett indicators was used [7]. A sample of LDHs and a magnetic stirrer were inserted into a small glass, the glass was put on a magnetic stirring device and the glass was filled with benzene Hammett indicator was added into benzene, the changes in color could be seen on the surface of the sample. The following indicators were used: bromothymol Blue $\left(\mathrm{pK}_{\mathrm{a}}=7,2\right)$, 4-chlor-2-nitroanilin $\left(\mathrm{pK}_{\mathrm{a}}=17,2\right)$, 4-chloranilin $\left(\mathrm{pK}_{\mathrm{a}}=26,5\right)$, purchased from Aldrich and 2,4,6-trinitroanilin $\left(\mathrm{pK}_{\mathrm{a}}=12,2\right), 2,4$-dinitroaniline $\left(\mathrm{pK}_{\mathrm{a}}=15,0\right), 4$-nitroanilin $\left(\mathrm{pK}_{\mathrm{a}}=18,4\right)$, purchased from Fluka. 
We have studied the adsorption of heavy metal anions $\left(\mathrm{CrO}_{4}^{2-}\right.$, $\mathrm{Cr}_{2} \mathrm{O}_{7}{ }^{2-}$ etc) by LDHs with general formula $\mathrm{Mg}_{\mathrm{x}} \mathrm{Al}_{\mathrm{y}}(\mathrm{OH})_{z}$ with different degree of the isomorphouse substitution. The sorption has been studied at intensive interfusion in neutral phase. The initial concentration of chromium anions $\mathrm{CrO}_{4}^{2-}$ was $1,7 \cdot 10^{-5} \mathrm{~mol} / \mathrm{l}$. The mass of sorbents was $1,0 \mathrm{~g}$ on $500 \mathrm{ml}$ of the probed water phase.

The concentration of adsorbed chromium ions in a water phase after adsorption in accordance with state and international standards was determined by spectrophotometric method using the diphenylhydrazine as indicator in an acid phase. The violet color appears as a result of reaction. The measuring was conducted at the waves of $540 \mathrm{~nm}$, because there is a maximum of absorption exactly at this wave-length.

\section{Results and discussion}

The properties of investigational samples of LDHs are shown in a Table 1 .

\begin{tabular}{cccc}
$\mathbf{M g} / \mathbf{M g}+\mathbf{A l}, \mathbf{m o l} / \mathbf{m o l}$ & $\mathbf{M g 0}, \mathbf{m a s s} \%$ & $\mathbf{V}, \mathbf{~ m l} / \mathbf{g}$ & $\mathbf{S}, \mathbf{~ m}^{2} \mathbf{g}$ \\
\hline 0,27 & 30 & 0,5 & 250 \\
\hline 0,72 & 50 & 0,2 & 200 \\
\hline 0,80 & 63 & 0,2 & 160 \\
\hline 0,86 & 70 & 0,2 & 180 \\
\hline
\end{tabular}

Table 1. Descriptions of investigational LDHs

1. táblázat A vizsgált réteges szerkezetü kettös hidroxidok leírása

Researches of chromium anions $\mathrm{CrO}_{4}^{2-}$ adsorption kinetics were also conducted with LDHs of different degree of isomorphous substitution.

The dependence of chromium ions on sorption times at different amount of sorbent with $0,27 \mathrm{~mol}$ part $\mathrm{MgO}$ can be seen in the Fig 1.

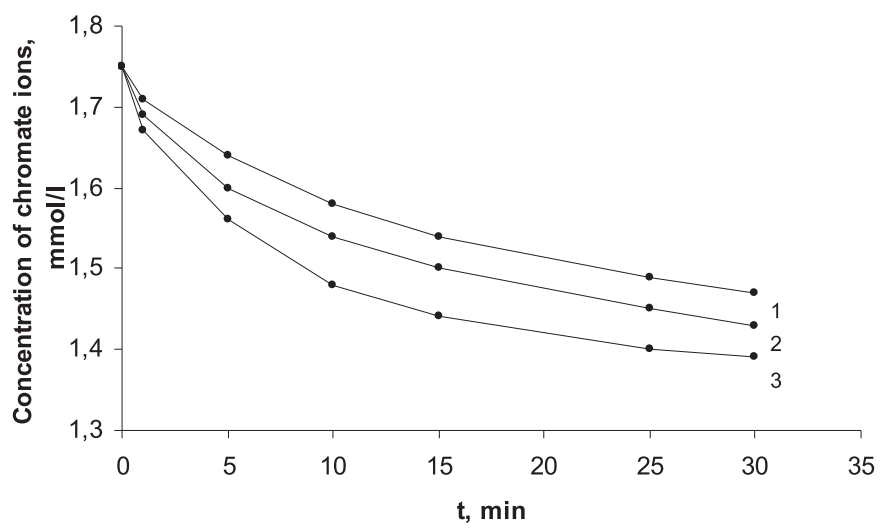

Fig 1. Adsorption of chromate anions in the present of different amounts of the LDHs $(1-0,1 \mathrm{~g}, 2-0,5 \mathrm{~g}, 3-1,0 \mathrm{~g})$

1. ábra A kromát anionok megkötése különbözö mennyiségü réteges szerkezetü kettös hidroxidok jelenlétében $(1-0,1 \mathrm{~g}, 2-0,5 \mathrm{~g}, 3-1,0 \mathrm{~g})$

According to our results we come to the conclusion that the highest degree of extraction of chromium ions is observed at sample with $0,52 \mathrm{~mol}$ part $\mathrm{MgO}$.

The experimental results on a change of reaction rate of absorption $\mathrm{CrO}_{4}^{2-}$ depending on $\mathrm{Mg} / \mathrm{Mg}+\mathrm{Al} \mathrm{mol} / \mathrm{mol}$ part are shown on Fig. 2.

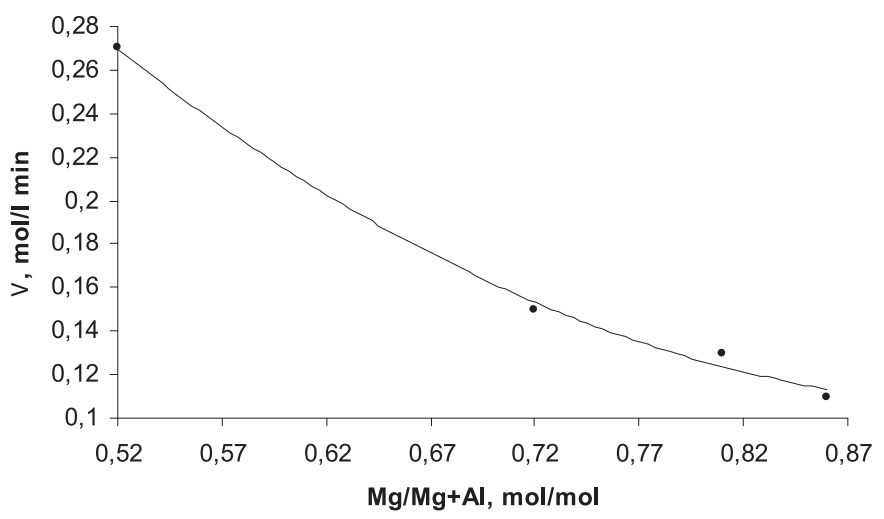

Fig 2. The change of adsorption rates of chromate anions on the different $L D H s$ with different $\mathrm{Mg} / \mathrm{Mg}+\mathrm{Al}$

2. ábra A kromát anionok adszorpció-sebességének változása különbözö $M g / M g+A l$ arányú, réteges szerkezetü kettős hidroxidokon

It is possible to assume, that the most degree of extraction of chromium ions is observed if we use the sorbent with $0,86 \mathrm{~mol}$ part $\mathrm{MgO}$. It is interesting to compare these results with the dependence between the number of basic sites and the degree of isomorphous substitutions (Fig. 3.) [8].

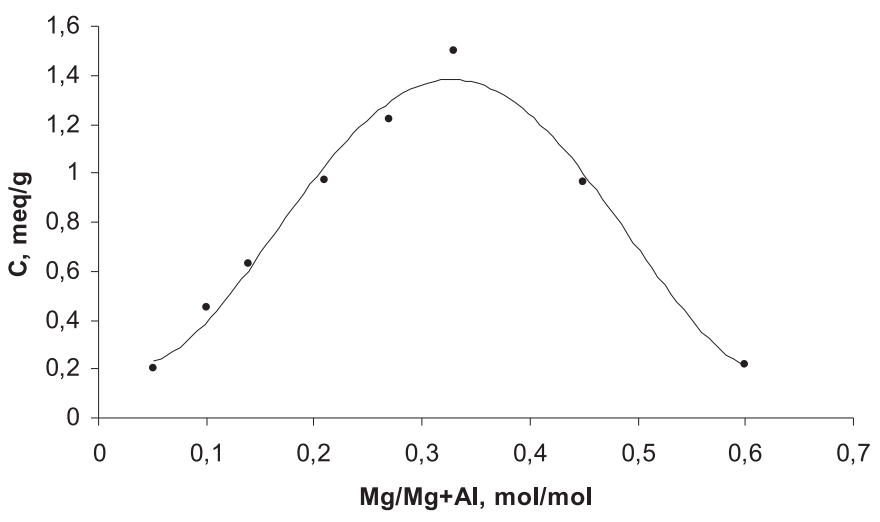

Fig. 3. The dependency of number of basic sites on the $\mathrm{Mg} / \mathrm{Al}$ molar ratio

3. ábra A bázikus helyek számának változása az Mg/Al mólarány függvényében

Fig. 3. shows reverse dependence which can not be explained only by the number of basic sites change. An increase of $\mathrm{MgO} /$ $\mathrm{Al}_{2} \mathrm{O}_{3}$ molar ratio firstly cause increase of the number of basic sites but this dependence show extreme behavior. The number of sites with high basicity also show extreme behavior too (Table 2.). For sample with $0,52 \mathrm{~mol}$ part $\mathrm{MgO}$ the concentration of acid sites is the followed: $\mathrm{H}_{0}=4,8-\mathrm{E}=0,4 \mathrm{meq} / \mathrm{g} ; \mathrm{H}_{0}=$ $1,5-\mathrm{E}=0,3 \mathrm{meq} / \mathrm{g}$.

\begin{tabular}{ccccccc}
$\mathbf{H}_{\mathbf{0}}$ & $\mathbf{2 6 , 5}$ & $\mathbf{1 8 , 4}$ & $\mathbf{1 7 , 2}$ & $\mathbf{1 5 , 0}$ & $\mathbf{1 2 , 2}$ & $\mathbf{7 , 2}$ \\
0,27 & - & 0,14 & 0,32 & 0,82 & 1,40 & 1,52 \\
\hline 0,72 & 0,01 & 0,09 & 0,40 & 1,11 & 1,21 & 1,22 \\
\hline 0,80 & 0,01 & 0,21 & 0,40 & 1,33 & 1,42 & 1,40 \\
\hline 0,86 & 0,02 & 0,32 & 0,68 & 1,41 & 1,55 & 1,58 \\
\hline
\end{tabular}

Table 2. The concentration of basic sites ( $E$, meq/g) of different strength $\left(H_{0}\right)$ in the LDHs with different molar ratio

2. táblázat A különbözö kötéserösségü $\left(H_{0}\right)$ bázikus helyek koncentrációja (E, meq/g) különbözö mólarányú réteges szerkezetủ kettős hidroxidokban 
Thus, adsorption of chromium anions is determined by the total influence of concentration of basic sites of sorbents and their basicity.

The values of dynamic capacities (E, meq/g) of investigational sorbents were determined (Table 3.).

\begin{tabular}{cl}
$\mathbf{M g} / \mathbf{M g}+\mathbf{A l}, \mathbf{~ m o l} / \mathbf{m o l}$ & E, meq/g \\
0,27 & $6,90 \cdot 10^{-2}$ \\
\hline 0,72 & $7,70 \cdot 10^{-2}$ \\
\hline 0,80 & $1,05 \cdot 10^{-2}$ \\
\hline 0,86 & $2,20 \cdot 10^{-2}$ \\
\hline
\end{tabular}

Table 3. The values of dynamic capacities of investigational $L D H s$

3. táblázat A vizsgált réteges szerkezetü kettős hidroxidok dinamikus szorpciós kapacitása

It is possible to notice that the sorption rate and dynamic exchange capacity have symbate changes. Most effective sorbents is a clay mineral with maintenance of sample with $0,86 \mathrm{~mol}$ part $\mathrm{MgO}$. The degree of chrome adsorption is about $90 \%$.

Thus, our researches showed that LDHs were effective sorbents for taking of heavy metals from industrial sewages.

\section{References}

[1] Vaccari, A.: Layered double hydroxides: present and future. V.Rives (Ed.), Nova Science Publishers, Inc, New York, 2002.

[2] Kapustin, A. E.: Structure and basic properties of layered double hydroxides. Chemistry and Chemical Technology 1992, № 35, p. 40-42.
[3] Kapustin, A.: Inorganic anion-exchangers. Russian Chemistry Review 1991, № 60, p. 1398-1416.

[4] Bolongini, M. - Perego, C.: Mg/Al mixed oxides prepared by coprecipitation and sol-gel routes. Microporous and Mesoporous Materials, 2003, № 66, p. 77-89.

[5] Kapustin, A.: Heterogeneous basic catalysis. Renata, Mariupol, 2008.

[6] Reichle, W. T.: Synthesis of anionic clay minerals (mixed metal hydroxides, hydrotalcites). Solid State Ionics, 1986 № 22, p. 135-141.

[7] Grekova, N. N. - Kapustin, A. E.: Indicator titration of heterogeneous basic catalysts. Catalysis and Petrochemistry, 1996, № 63, p. 25-27.

[8] Parida, K. - Das, J.: Mg/Al hydrotalcites: preparation, characterization and ketonisation of acetic acid. Journal of Molecular Catalysis A: Chemical, 2000, № 151, p. 185-192.

\section{A réteges szerkezetű kettős hidroxidok szerkezetének és összetételének hatása kromát anionok szorpciós sajátságaira}

A közleményben nehézfémeket tartalmazó anionok vízből történô megkötését vizsgáljuk különbözô összetételú agyagásványokon. Tanulmányozzuk, hogy a szorbensek bázikus jellege, a szorpciós folyamatok kinetikája és az agyagásványok anioncserélô kapacitása miként befolyásolják az anionok megkötôdését. Összefüggést állapítottunk meg az agyagok összetétele és anioncserélô kapacitása között.

Kulcsszavak: réteges szerkezetú kettôs hidroxidok, szorpció, bázikusság, kinetika

Ref.: http://dx.doi.org//10.14382/epitoanyag-jsbcm.2010.9

Butenko, E. - Kapustin, A..: Layered double hydroxides structure and composition influence on sorption characteristics relative to chromium anions. Építőanyag, 62. évf. 2. szám (2010), 43-45. p. 